\title{
Determinants of Injuries in Passenger Vessel Accidents
}

\author{
Tsz Leung Yip \\ C. Y. Tung International Centre for Maritime Studies \\ Department of Logistics and Maritime Studies \\ The Hong Kong Polytechnic University \\ Hong Kong \\ t.l.yip@polyu.edu.hk \\ Di Jin* \\ Marine Policy Center \\ Woods Hole Oceanographic Institution \\ Woods Hole, Massachusetts 02543 \\ Phone: 508-289-2874 \\ Fax: 508-457-2034 \\ djin@whoi.edu \\ Wayne K. Talley, Executive Director \\ Maritime Institute \\ Old Dominion University \\ Norfolk, Virginia 23529 \\ Phone: 757-683-3534 \\ Fax: 757-683-5639 \\ wktalley@odu.edu
}

*Corresponding author

\begin{abstract}
This paper investigates determinants of crew and passenger injuries in passenger vessel accidents. Crew and passenger injury equations are estimated for ferry, ocean cruise, and river cruise vessel accidents, utilizing detailed data of individual vessel accidents that were investigated by the U.S. Coast Guard during the time period 2001-2008. The estimation results provide empirical evidence (for the first time in the literature) that crew injuries are determinants of passenger injuries in passenger vessel accidents.
\end{abstract}

Keywords: ferry; ocean cruise; river cruise; vessel accidents.

\section{Acknowledgements}

This study was partially funded by the Hong Kong Polytechnic University (Code: APL59). Di Jin would like to thank the support from the J. Seward Johnson Fund in Support of the Marine Policy Center of the Woods Hole Oceanographic Institution. 


\section{Introduction}

Passenger vessels include cruise and ferry passenger vessels. Cruise vessels specialize in providing pleasure (rather than transportation) voyages for passengers. If a vessel voyage returns its passengers to the port where they boarded the vessel, the vessel voyage will not have provided passenger transportation service. Cruise vessel voyages are classified according to the primary body-of-water utilized by the voyages. If the primary body-of-water utilized by cruise vessels is an ocean, river or harbor, the cruise voyage has been described as an ocean, river or harbor cruise voyage, respectively (Veronneau and Roy, 2012).

On 13 January 2012, the port side of the cruise vessel Costa Concordia hit a reef, losing 32 of those aboard. Other cruise vessel accidents, where a relatively large number of fatalities have occurred, include the TSMS Lakonia accident in 1963 (128 fatalities), the Aleksandr Suvorov accident in 1983 (177 fatalities), and the Bulgaria accident in 2011 (122 fatalities). Although cruise vessel accidents do occur, they are relatively few in number when compared to the number of cruise vessel sailings.

Unlike cruise vessels, ferry vessels specialize in providing transportation voyages. Ferry vessels transport passengers or passengers and their vehicles (autos and trucks). Ferry vessels that transport passengers and their vehicles are described as roll-on-roll-off ferries. ${ }^{1}$ The instability of roll-on-roll-off ferries is a safety concern (National Transportation Safety Board, 1989). The vessels have large holes that allow for the loading (roll-on) and the unloading (roll-off) of vehicles, thus precluding vertical watertight bulkheads that are standard features for most commercial vessels. If water gets in a vessel and causes a pronounced list, the ferry will capsize and sink. If loading doors are breached, 60\% of roll-on-roll-off ferries will sink within ten minutes (Barnard, 1987).

\footnotetext{
${ }^{1}$ For a discussion of the risk of roll-on roll-off ferries incurring collision and grounding accidents see Otto et al. (2002).
} 
Ferries provide scheduled passenger service over a fixed route that may involve multistops (Wergeland, 2012). In urban areas, a scheduled passenger (for-hire) service over a fixed route is defined as a transit service (Talley, 2006). Ferry service, among urban transit services, has the distinction of utilizing the largest transit vehicle in the provision of urban transit service.

A safety concern for ferry vessels is human error in vessel operation. ${ }^{2}$ New York's Staten Island ferries have been involved in numerous accidents, resulting in injuries to hundreds of passengers; these accidents have often been attributed to human errors such as inattentiveness, poor judgment and negligence by the crew (McIntire, 2003). The collision between the ferry Sea Smooth and the passenger vessel Lamma IV in Hong Kong occurred in October 2012 with 39 killed and 92 injuries. This accident is the worst vessel accident with respect to the number of injuries in Hong Kong since 1971. The sinking of the ferry Sewol in Korea in April 2014 resulted in the death of 295, mostly high school students. The capsizing of the vessel was caused by overloading and not properly securing cargo onboard. It is suspected that the poor performance of the crew contributed to the large passenger death toll.

U.S. cruise and ferry passenger vessels are subject to U.S. Coast Guard passenger safety regulations. Non-U.S. passenger vessels are subject to the passenger safety regulations of their flag states. However, all vessels entering U.S. ports for the purposes of boarding passengers for cruise are subject to U.S. Coast Guard regulations. The 1974 International Maritime Organization (IMO) Convention, the Athens Convention, set liability limits for personal injuries and deaths aboard passenger vessels. The International Convention for the Safety of Life at Sea (SOLAS) as well as other regulations require cruise crews to undertake extensive training, certification, drills and scenarios for

\footnotetext{
${ }^{2}$ For discussion of human and other causes of vessel accidents, see Millar (1980) and Staff (1998).
} 
accidents, including the evacuation of a ship. Cruise vessel crews are also expected to know where the lifeboats, life rafts and life preservers are for every person on board the vessel.

The purpose of this paper is to investigate determinants of injuries (crew and passenger) in cruise and ferry passenger vessel accidents. In particular, the paper investigates whether there a positive relationship between passenger injuries and crew injuries in passenger vessel accidents. That is to say, do crew injuries in passenger vessel accidents contribute to passenger injuries in these accidents? The answer to this question will have significant policy implications with respect to the safety training of a passenger vessel's crew. When crew members are injured in a vessel accident, their ability to maintain passenger safety will be compromised. Effective assistance provided by a vessel's crew to its passengers in the event of a vessel accident may be crucial in preventing passenger injuries as well as their severity.

The remainder of the paper is organized as follows: Section 2 presents a literature review. Section 3 posits passenger vessel accident crew and passenger injury functions, followed by a discussion of data in Section 4. Section 5 presents equation estimation results for ferry, ocean cruise, and river cruise vessels. Section 6 sets forth conclusions.

\section{Literature Review}

The literature investigating injuries aboard passenger vessels has focused on injuries attributable to vessel accidents, those attributable to evacuations and those attributable to the actions of passengers themselves. In an analysis of individual cruise vessel accidents investigated by the U.S. Coast Guard that occurred during the time period 1991-2001, Talley et al. (2008) concluded that ocean cruise vessel accidents, as opposed to those for inland waterway and harbor cruise vessels, are more likely to incur 
injuries. The probability of accident-related injuries will be greater if the cause of the accident is a human as opposed to an environmental or vessel cause. Examples of human causes include the lack of training, stress, lack of knowledge, inadequate supervision, psychological impairment, and intoxication. Examples of environmental causes include adverse weather, shoaling, debris, a submerged object and adverse current/sea conditions. Examples of vessel causes include vessel stress fracture, corrosion, fouled propeller, dragging anchor, steering failure and propulsion failure.

In an analysis of individual ferry vessel accidents investigated by the U.S. Coast Guard that occurred during the time period 1981-1991, Talley (2002) concluded that injuries for ferry vessel accidents are expected to be higher for fire/explosion than for material/equipment and grounding accidents. The inattentiveness, poor judgment and negligence by crew members have resulted in ferry accidents and therefore injuries to ferry passengers (McIntire, 2003). Safety assessment criteria for enhancing the passenger safety of passenger ferry services include: 1) safety equipment, 2) ship structure, 3) shipping documentation inspection, 4) safety instruction, 5) navigation and communication, and 6) crew members' ability (to respond to an emergency and knowledge of rescue procedures). Crew members’ ability was found by Lu and Tseng (2012) to be the most important criterion, followed by safety equipment, for enhancing ferry passenger safety. "Safety training and emergency preparedness are positively associated with safety behavior, including safety compliance and safety participation” (Lu and Yang, 2011, p. 339).

The evacuation of passenger vessels requires "mustering passengers to safe areas, counting and accounting for passengers, and controlling and guiding their movements” (Vanem and Ellis, 2010, p. 788). The crew is often placed in stressful situations, especially when there are a large number of passengers to be evacuated, their locations on 
the vessel are unknown and whether they require assistance is unknown. Confusion between passengers and crew can arise because of ineffective communication by the crew. Passenger injuries attributed to the actions or inactions of the crew during a vessel's evacuation can be eliminated and/or reduced by providing adequate crew training. Cruise vessel crews are also expected to know where the lifeboats, life rafts and life preservers are for every person on board (Kim et al., 2004). A discussion of developing evacuation scenarios for passenger vessels based upon maritime safety regulations is found in Vanem and Skjong (2006).

“The fact that cruise ships carry large and diverse groups of people means that their officers, staff and crew need a clear understanding of human responses in emergencies and an ability to deal with crowds. The areas directly related to human behavior and crowd control might include the ability of giving clear and reassuring order, dealing with passengers' special needs and keeping order, reducing or avoiding panic” (Lois et al., 2004, p. 107). “Confusion is often caused by poor or ineffective communication between the various parties involved, such as the misunderstanding arising from a range of native languages among the crew. To a large extent, this type of error can be reduced by careful selection and adequate training of crew" (Lois et al., 2004, p. 108). The knowledge or experience and information flow among the crew of a cruise vessel may be inadequate for promoting cruise vessel safety. A discussion of human error and vessel accidents is found in McIntire (2003) and Millar (1980).

Actions of passengers aboard cruise vessels may also contribute to their injuries, e.g., falls (especially by older passengers), resulting in passenger concussions, fractures and hemorrhages. The risk for such falls may depend upon whether the vessel has straight or circular stairwells and whether handrails, grab bars, carpeting or slip-resistant surfaces are present and whether passengers are intoxicated (from alcohol consumption) at the 
time of the fall. Exposure by passengers to on-board infectious epidemics, consisting of viral dysentery and respiratory infections, will weaken passengers if caught and thus increase their likelihood of falling and incurring injuries (Bansal et al., 2007).

\section{Vessel Accident Injuries}

Since the safety of a vessel's crew depends to a large extent on the vessel's safety, a positive relationship exists between accident vessel damage severity and injury severity. In the study, the number of crew injuries in a passenger vessel accident $(C)$ is posited to be a function of the vessel's accident damage severity $(D)$, i.e.,

$$
C=f(D)
$$

$D$, in turn, is expected to be affected by the type of vessel accident (a), vessel characteristics (c), type of vessel propulsion (p), type of vessel hull construction (h), visibility conditions (v), and time of vessel accident (t), i.e.,

$$
D=g(\mathbf{a}, \mathbf{c}, \mathbf{p}, \mathbf{h}, \mathbf{v}, \mathbf{t})
$$

Types of vessel accidents (a) found in U.S. Coast Guard statistics include: allusion, ${ }^{3}$ capsize, collision, explosion, fire, flooding, grounding, material failure, ${ }^{4}$ and sinking, as well as variables describing post-vessel-accident vessel conditions: abandonment, vessel adrift, loss of power, and loss of stability or maneuverability. In addition, whether a vessel caused environmental damage say from a pollution discharge and whether a vessel requested emergency response are also found in the U.S. Coast Guard statistics. The damage severity and crew injuries incurred by a vessel accident are expected to be greater

\footnotetext{
${ }^{3}$ An allision accident occurs when a vessel strikes a stationary object (not another vessel) on the water surface. A collision accident occurs when a vessel strikes or was struck by another vessel on the water surface. A grounding accident occurs when the vessel is in contact with the sea bottom or a bottom obstacle.

${ }^{4}$ A material-failure accident typically involves equipment failure on board the vessel.
} 
for allision and collision vessel accidents given the speed of impact. Otherwise, the $a$ priori relationship between type of accident and damage severity $(D)$ is indeterminate.

Vessel characteristics (c) include vessel size, age, flag, propulsion, and hull construction material. The gross tonnage is a measure of vessel size. Since larger vessels carry larger numbers of crews and passengers, the number of injuries is expected to increase with vessel size. It is expected that the number of injuries for an older vessel will be greater than that of a newer vessel. The flag of a cruise vessel is distinguished by whether the flag is a U.S. flag or not. Given that the U.S. flag registry has some of the stricter ship safety regulations among ship registries, a negative relationship is expected between vessel accident injuries and U.S. flag.

Vessel propulsion (p) is distinguished by whether the vessel has a diesel engine, gasoline engine, or a turbine engine. Vessel hull type (h) is distinguished by the type of hull material, i.e., by whether the hull material is aluminum, fiberglass, and steel. Since steel is the strongest of these materials, it is expected that a constructed with steel will incur less damage severity as well as crew injuries, all else held constant.

Visibility at the time of an accident (v) is distinguished between whether it was nighttime versus daytime at the time of the accident. Accident year $(\mathbf{t})$ is included in the model to capture the time trend. Adverse visibility is expected to increase the risk of a vessel accident, and the impact on $D$ and crew injuries $(C)$ is positive.

Replacing the vectors in equation (2) with the above described measurement variables (x) and then substituting equation (2) into equation (1), one obtains the following reduced-form equation for crew injuries:

$$
C=F(\mathbf{x})
$$

The number of passengers injured in a passenger vessel accident $(P)$ is posited to be a function of crew injuries and vessel damage severity, i.e., 


$$
P=h(\mathrm{C}, D)
$$

Note that equation (4) distinguishes between the effect of vessel damage severity and the number of crew injuries from a passenger vessel accident on the number of passenger injuries resulting from a passenger vessel accident.

\section{Data}

Data used in the estimations of Equations (3) and (4) consist of detailed records of individual vessel accidents that were investigated by the U.S. Coast Guard during the 8year time period 2001-2008 and were extracted from the Coast Guard’s Marine Information for Safety and Law Enforcement (MISLE) database. The U.S. Coast Guard compiles vessel casualty and pollution statistics and maintains a computer database of detailed records on vessel accident and pollution events in U.S. waters. For the vessel accident data, each observation is a vessel involved in an accident. The name and format of the database have changed over the years. Between 1981 and 1991, the vessel casualty database was called CASMAIN. From 1992 to 2001, vessel casualty and pollution records were incorporated into a larger database called Marine Safety Information System (MSIS). Since December 2001, the database has transitioned to the MISLE information system.

Three MISLE data tables were used to compile the data set for this study. The three data tables include: the Vessel Event Table (MisleVslEvents), the Vessel Table (MisleVessel), and Personal Injury Table (MisleInjury). The data set includes 1,795, 263, and 83 accident records (or observations) for ferry, ocean cruise, and river cruise vessels, respectively.

Variables used in the equation estimation, their specific measurements, and descriptive statistics (mean and standard deviation) appear in Table 1. The means for the 
two dependent variables, crew injuries $(C)$ and passenger injuries $(P)$, are 0.028 and 0.191 persons per accident, respectively, for ferry vessels, 0.034 and 0.392 persons per accident for ocean cruise vessels, and 0.277 and 0.217 persons per accident for river cruise vessels. The mean statistics for the explanatory variables reveal that the two most frequent passenger vessel accident types are material failure (44.6\%, 26.2\%, and 32.5\% for ferry, ocean cruise, and river cruise vessels, respectively) and loss of maneuverability (30.0\%, $18.6 \%$, and $21.7 \%$ for ferry, ocean cruise, and river cruise vessels, respectively). Other frequent accident types include damage to the environment (17.9\%) for ocean cruise vessels and allision (15.7\%) for river cruise vessels. The average size of a ferry involved in an accident is 1,282 gross tons and its average age is 22.9 years. The average size of an ocean cruise ship involved in an accident is 54,369 gross tons and its average age is 13.4 years. For a river cruise ship, the means are 1,677 gross tons and 22.1 years, respectively. Almost all ferry and all river cruise vessel are U.S. flagged. In contrast, only $10.6 \%$ of ocean cruise vessels are U.S. flagged. Most passenger vessels are under diesel propulsion with steel hulls. Also, 29.5\%, 39.9\%, and 48.2\% of the accidents occurred at nighttime for ferry, ocean cruise, and river cruise vessels, respectively. Whether a vessel involved in an accident incurred damage or no damage is measured by a binary variable. The mean for the binary variable, vessel damage severity $(D)$, is 0.373 , 0.327, and 0.602 for ferry, ocean cruise, and river cruise vessels, respectively. In other words, among the accident cases in the three data sets, $37.3 \%, 32.7 \%$, and $60.2 \%$ are classified as vessel “damaged” or "total constructive loss” $(D=1)$, the rest are classified as vessel “undamaged” $(D=0)$.

\section{Estimation Results}

As noted above, we develop estimations for two sets of models (equations 3 and 
4) for crew injury $(C)$ and passenger injuries $(P)$. The dependent variables in both equations (3) and (4) are counts of rare events. Typically, vessel accidents with injuries are infrequent; also, if injuries occur, they are few in number. The preponderance of zeros and the small values and discrete nature of accident crew and passenger injuries suggest that the estimation could be improved, relative to ordinary least squares (OLS), by using Poisson regression, which accounts for these characteristics. We have also tested alternative specifications including negative binomial regression but the results were less satisfactory and thus are not reported here.

Table 2 reports the results from three separate Poisson estimations for crew injury (C) equation (3) using the data sets for ferry, ocean cruise and river cruise vessels, respectively. ${ }^{5}$ The table includes results for statistically significant explanatory variables and constant terms. In each model, the chi-square statistic is large and statistically significant at the 0.01 level. ${ }^{6}$ For ferry vessels, the estimation results suggest that a greater number of crew injuries are expected if the vessel has capsized or set adrift following an accident and if the vessel is involved in collision or allision accident. More crew injuries are also expected if the vessel has a steel hull. The explanation for this result may be due to the fact that steel-hulled ferry vessels are typically larger and therefore carry a great number of crew individuals. For ocean cruise vessels, more crew injuries are expected if a vessel is involved in a collision accident or it is lost its maneuverability. A smaller number of crew injuries is expected if the vessel is older or has a steel hull. In the case of river cruise vessels, a larger number of crew injuries are expected if a vessel is involved

\footnotetext{
${ }^{5}$ A number of extensions of the Poisson model that relax the assumption that the variance of dependent variable $(y)$ equals to its mean have been proposed (Greene 2012). We used an overdispersion test proposed by Cameron and Trivedi (1990). Under the hypothesis, $[\mathrm{y}-\mathrm{E}(\mathrm{y})]^{2}-\mathrm{E}(\mathrm{y})$ has mean 0 . In all of our model runs, the null hypothesis of equidispersion could not be rejected, and Poisson model was used.

${ }^{6}$ The critical values necessary for significance at the 0.01 level for four and five degrees of freedom are 13.28 and 15.09, respectively. The chi-squared statistic for ferry is $49.60>15.09$, ocean cruise $53.60>$ 13.28 , and river cruise $51.79>15.09$.
} 
in an explosion or grounding accident, or if the vessel has lost its maneuverability. As expected, a greater number of crew injuries occur on larger river-cruise vessels involved in accidents. As for ocean cruise vessels involved in accidents, a smaller number of crew injuries are associated with older river-cruise vessels involved in accidents.

Note that the crew-injury variable in equation (3) is a dependent variable but an explanatory variable in equation (4); thus its error term observations as a stochastic variable in equation (3) could be correlated with the error terms of the dependent and stochastic variable $(P)$ in equation (4). To address this potential problem, equation (4) is estimated through a two-step procedure, where the fitted crew injury $\left(C_{f i t}\right)$ variable is deduced and used as an instrument of $(C)$ in the estimation of equation (4). Specifically, the first step involves using the estimate of equation (3) to obtain the fitted crew injury $\left(C_{f i t}\right)$ variable, whose observations are obtained by substituting values of the explanatory variables in estimated equation (3) and solving. In the second step, an estimate of equation (4) is obtained using the instrumental variable $\left(C_{f i t}\right)$ and the binary vessel damage severity variable $(D)$ as explanatory variables.

The estimation results of passenger injury equation (4) in Table 3 indicate that there is a positive relationship between the number of passenger injuries and crew injuries in ferry, ocean cruise and river cruise passenger vessel accidents, i.e., an increase in the number of crew injuries in ferry, ocean cruise and river cruise passenger vessel accidents is expected to result in an increase in the number of passenger injuries in these accidents. ${ }^{7}$ The empirical findings thus suggest that the safety of passengers on board passenger vessels will depend in part upon the safety of vessel crews on board these vessels.

\section{Conclusion}

\footnotetext{
${ }^{7}$ The values of chi-square statistic are 461.24 for ferry, 666.43 for ocean cruise, and 26.89 for river cruise, all exceeding the 9.21 critical value necessary for significance at the 0.01 level for two degrees of freedom.
} 
This study investigates determinants of passenger vessel accident injuries using Poisson regression and empirical data on ferry, ocean cruise, and river cruise vessel accidents (obtained from the U.S. Coast Guard). Unlike previous studies, the relationship between passenger and crew injuries in passenger vessel accidents is examined. The empirical results suggest that the number of passenger injuries is positively related to the number of crew injuries in ferry, ocean cruise and river cruise passenger vessel accidents. Thus, the safety of passengers on board passenger vessels depends on the safety of crew members on board these vessels. An important policy implication of the study is that the safety of passengers and crew members aboard ferry and cruise passenger vessels can be improved via the training of vessel crew members to ensure their safety in the event of a vessel accident. With cruise vessels increasing in size and carrying greater numbers of crew members and passengers, an emphasis on improving the safety of passenger-vessel crew members may lead to significant safety benefits for crew members and passengers.

Although the study has identified the links among vessel damage severity, crew injury and passenger injury, we were unable to investigate specific causes and types of crew injuries under different vessel accident scenarios for lack of data. Effective crew safety training can be achieved, and crew injury can be significantly reduced, only when our understanding of the causes of injuries under various vessel conditions is improved through future investigations. Similarly, due to data limitation, crew-training level was not explicitly modeled in the current study. A future study should include variables capturing crew-training levels, so that the effectiveness of training on crew safety and in turn passenger safety can be assessed. Finally, future studies should examine specific interactions between passengers and vessel crew under different accident scenarios to improve our understanding of the relationship of passenger and crew injuries, so that a more comprehensive safety program for passenger vessels can be developed. 


\section{References}

Bansal, V., Fortlage, D., Lee, J.G., Hill, L.L., Potenza, B, Coimbra, R., 2007. Significant injury in cruise ship passengers. American Journal of Preventive Medicine 33(3), 219221.

Barnard, B., 1987. Ferry loss raises questions: concept of roll-on vessels faces spotlight again. Journal of Commerce. March 10, 16A.

Cameron, A., Trivedi P., 1990. Regression-based tests for overdispersion in the Poisson model. Journal of Econometrics 46(3), 347-364.

Greene, W.H., 2012. Econometric Analysis, 7th Edition. Prentice Hall, Upper Saddle River, NJ.

Kim, H., Park, J.H., Lee, D., Yang, Y., 2004. Establishing the methodologies for human evacuation simulation in marine accidents. Computers and Industrial Engineering 46(4), 725-740.

Lois, P., Wang, J., Wall, A., Ruxton, T., 2004. Formal safety assessment of cruise ships. Tourism Management 25(1), 93-109.

Lu, C.S., Yang, C.S., 2011. Safety climate and safety behavior in the passenger ferry context. Accident Analysis and Prevention 43(1), 329-341.

Lu, C.S., Tseng, P.H., 2012. Identifying crucial safety assessment criteria for passenger ferry services. Safety Science 50(7), 1462-1471.

McIntire, M., 2003. History of human error found in ferry accidents. New York Times. November 1.

Millar, I.C., 1980. The need for a structure policy towards reducing human-factor errors in marine accidents. Maritime Policy and Management 7(1), 9-15.

National Transportation Safety Board, 1989. Safety study: passenger vessels operating from US ports. NTSB/SS-89/01. US Government Printing Office, Washington, DC,175 pages.

Otto, S, Pedersen, P.T., Samuelides, M., Sames, P.C., 2002. Elements of risk analysis for collision and grounding of a roro passenger ferry. Marine Structures 15(4-5), 461-474.

Staff, 1998. Human error causes most sea accidents. Journal of Commerce. April 7, 5A.

Talley, W.K., 2002. The safety of ferries: an accident injury perspective. Maritime Policy and Management 29(3), 331-338.

Talley, W.K., 2006. Classifying urban passenger transportation services. In Essays in Transport Economics, Editors, Coto-Millan, P., Inglada, V., Springer Publishing, Co., pp. 67-79. 
Talley, W.K., Jin, D, Kite-Powell, H., 2008. Determinants of the severity of cruise vessel accidents. Transportation Research Part D 13(2), 86-94.

Vanem, E., Ellis, J., 2010. Evaluating the cost-effectiveness of a monitoring system for improved evacuation from passenger ships. Safety Science 48(6), 788-802.

Vanem, E., Skjong, R., 2006. Designing for safety in passenger ships utilizing advanced evacuation analyses - a risk based approach. Safety Science 44(2), 111-135.

Veronneau, S., Roy, J., 2012. Cruise lines and passengers. In The Blackwell Companion to Maritime Economics. Editor, Talley, W.K., Wiley-Blackwell Publishing, Oxford, U.K., pp. 138-160.

Wergeland, T., 2012. Ferry passenger markets. In The Blackwell Companion to Maritime Economics. Editor, Talley, W.K., Wiley-Blackwell Publishing, Oxford, U.K., pp. 161183. 
Table 1. Variable Definitions and Descriptive Statistics

\begin{tabular}{llccc}
\hline Variable & Measurement & $\begin{array}{c}\text { Ferry } \\
\text { Mean } \\
\text { (std. dev.) }\end{array}$ & $\begin{array}{c}\text { Ocean Cruise } \\
\text { Mean } \\
\text { (std.dev.) }\end{array}$ & $\begin{array}{c}\text { River Cruise } \\
\text { Mean } \\
\text { (std.dev.) }\end{array}$ \\
\hline Dependent Variable & & & \\
Crew injury $(C)$ & $\begin{array}{l}\text { Number of crew } \\
\text { injuries }\end{array}$ & 0.028 & 0.034 & 0.277 \\
Passenger injury $(P)$ & $\begin{array}{l}\text { Number of passenger } \\
\text { injuries }\end{array}$ & $(0.264)$ & $(0.384)$ & $(0.979)$ \\
& $(3.185)$ & 0.392 & 0.217 \\
& & & $(4.438)$ & $(1.116)$
\end{tabular}

Explanatory Variables

Type of vessel accident

\begin{tabular}{|c|c|c|c|c|}
\hline Abandonment & $\begin{array}{l}1 \text { if vessel abandoned, } \\
0 \text { otherwise }\end{array}$ & $\begin{array}{c}0.001 \\
(0.033)\end{array}$ & $\begin{array}{c}0 \\
(0)\end{array}$ & $\begin{array}{l}0 \\
(0)\end{array}$ \\
\hline Adrift & $\begin{array}{l}1 \text { if vessel set adrift, } 0 \\
\text { otherwise }\end{array}$ & $\begin{array}{c}0 \\
(0)\end{array}$ & $\begin{array}{c}0.004 \\
(0.062)\end{array}$ & $\begin{array}{c}0.012 \\
(0.110)\end{array}$ \\
\hline Allision & $\begin{array}{l}1 \text { if an allision, } 0 \\
\text { otherwise }\end{array}$ & $\begin{array}{l}0.066 \\
(0.249)\end{array}$ & $\begin{array}{l}0.046 \\
(0.209)\end{array}$ & $\begin{array}{l}0.157 \\
(0.366)\end{array}$ \\
\hline Capsize & $\begin{array}{l}1 \text { if a capsize, } 0 \\
\text { otherwise }\end{array}$ & $\begin{array}{c}0.001 \\
(0.033)\end{array}$ & $\begin{array}{l}0 \\
(0)\end{array}$ & $\begin{array}{c}0 \\
(0)\end{array}$ \\
\hline Collision & $\begin{array}{l}1 \text { if a collision, } 0 \\
\text { otherwise }\end{array}$ & $\begin{array}{l}0.014 \\
(0.117)\end{array}$ & $\begin{array}{l}0.057 \\
(0.232)\end{array}$ & $\begin{array}{c}0.036 \\
(0.188)\end{array}$ \\
\hline $\begin{array}{l}\text { Emergency } \\
\text { response }\end{array}$ & $\begin{array}{l}1 \text { if vessel requested } \\
\text { emergency response, } 0 \\
\text { otherwise }\end{array}$ & $\begin{array}{l}0.003 \\
(0.058)\end{array}$ & $\begin{array}{l}0.019 \\
(0.137)\end{array}$ & $\begin{array}{c}0.024 \\
(0.154)\end{array}$ \\
\hline $\begin{array}{l}\text { Environmental } \\
\text { damage }\end{array}$ & $\begin{array}{l}1 \text { if vessel caused } \\
\text { environmental } \\
\text { damage, } 0 \text { otherwise } \\
1 \text { if an explosion }\end{array}$ & $\begin{array}{l}0.030 \\
(0.171)\end{array}$ & $\begin{array}{l}0.179 \\
(0.384)\end{array}$ & $\begin{array}{c}0.036 \\
(0.188)\end{array}$ \\
\hline Explosion & $\begin{array}{l}\text { vessel accident, } 0 \\
\text { otherwise }\end{array}$ & $\begin{array}{c}0 \\
(0)\end{array}$ & $\begin{array}{l}0 \\
(0)\end{array}$ & $\begin{array}{c}0.012 \\
(0.110)\end{array}$ \\
\hline Fire & $\begin{array}{l}1 \text { if a fire vessel } \\
\text { accident, } 0 \text { otherwise }\end{array}$ & $\begin{array}{c}0.012 \\
(0.110)\end{array}$ & $\begin{array}{l}0.076 \\
(0.266)\end{array}$ & $\begin{array}{c}0.012 \\
(0.110)\end{array}$ \\
\hline Flooding & $\begin{array}{l}1 \text { if a flooding vessel } \\
\text { accident, } 0 \text { otherwise }\end{array}$ & $\begin{array}{l}0.018 \\
(0.134)\end{array}$ & $\begin{array}{l}0.023 \\
(0.100)\end{array}$ & $\begin{array}{c}0.012 \\
(0.110)\end{array}$ \\
\hline Grounding & $\begin{array}{l}1 \text { if a grounding vessel } \\
\text { accident, } 0 \text { otherwise }\end{array}$ & $\begin{array}{c}0.047 \\
(0.212)\end{array}$ & $\begin{array}{l}0.061 \\
(0.200)\end{array}$ & $\begin{array}{c}0.072 \\
(0.261)\end{array}$ \\
\hline $\begin{array}{l}\text { Loss of electrical } \\
\text { power }\end{array}$ & $\begin{array}{l}1 \text { if vessel lost } \\
\text { electrical power, } 0 \\
\text { otherwise }\end{array}$ & $\begin{array}{l}0.050 \\
(0.218)\end{array}$ & $\begin{array}{c}0.057 \\
(0.232)\end{array}$ & $\begin{array}{c}0.036 \\
(0.188)\end{array}$ \\
\hline Maneuverability & $\begin{array}{l}1 \text { if vessel had a } \\
\text { maneuverability } \\
\text { problem, } 0 \text { otherwise }\end{array}$ & $\begin{array}{c}0.300 \\
(0.459)\end{array}$ & $\begin{array}{c}0.186 \\
(0.390)\end{array}$ & $\begin{array}{c}0.217 \\
(0.415)\end{array}$ \\
\hline Material failure & $\begin{array}{l}1 \text { if a material-failure } \\
\text { accident, } 0 \text { otherwise }\end{array}$ & $\begin{array}{l}0.446 \\
(0.497)\end{array}$ & $\begin{array}{l}0.262 \\
(0.441)\end{array}$ & $\begin{array}{l}0.325 \\
(0.471)\end{array}$ \\
\hline Sinking & $\begin{array}{l}1 \text { if a sinking accident, } \\
0 \text { otherwise }\end{array}$ & $\begin{array}{c}0 \\
(0)\end{array}$ & $\begin{array}{c}0 \\
(0)\end{array}$ & $\begin{array}{c}0 \\
(0)\end{array}$ \\
\hline Stability & $\begin{array}{l}1 \text { if vessel lost } \\
\text { stability, } 0 \text { otherwise }\end{array}$ & $\begin{array}{c}0 \\
(0)\end{array}$ & $\begin{array}{l}0 \\
(0)\end{array}$ & $\begin{array}{l}0 \\
(0)\end{array}$ \\
\hline
\end{tabular}


Vessel characteristics

$\begin{array}{llccc}\text { Vessel gross ton } & \text { vessel size in gross } & 1281.796 & 54368.981 & 1677.096 \\ & \text { tons } & (1430.082) & (34663.127) & (2267.907) \\ \text { Vessel age } & \text { vessel age in years } & 22.855 & 13.403 & 22.072 \\ & & (17.975) & (10.857) & (27.457) \\ \text { US flag } & 1 \text { if a US flag vessel, } 0 & 0.996 & 0.106 & 1 \\ & \text { otherwise } & (0.062) & (0.300) & (0)\end{array}$

Type of vessel propulsion

Diesel engine $\quad 1$ if vessel is under

$\begin{array}{lccc}\text { diesel propulsion, } 0 & 0.887 & 0.863 & 0.361 \\ \text { otherwise } & (0.317) & (0.344) & (0.483)\end{array}$

Gasoline engine

1 if vessel is under

Turbine engine $\quad 1$ if vessel is under

$\begin{array}{lccc}\text { gasoline propulsion, } 0 & 0.002 & 0 & 0.024 \\ \text { otherwise } & (0.047) & (0) & (0.154)\end{array}$

turbine propulsion, 0

otherwise

0.001

$(0.024)$

0.023

(0.150)

0

(0)

Type of vessel hull construction

$\begin{array}{llccc}\text { Aluminum hull } & \begin{array}{l}1 \text { if aluminum hull } \\ \text { construction, } 0\end{array} & 0.274 & 0 & 0.048 \\ \text { Fiberglass hull } & \begin{array}{l}\text { otherwise } \\ 1 \text { if fiberglass hull } \\ \text { construction, } 0\end{array} & 0.446) & (0) & (0.215) \\ \text { Otherwise } & (0.130) & 0 & 0.024 \\ \text { Steel hull } & \begin{array}{l}1 \text { if steel hull } \\ \text { construction, } 0\end{array} & 0.697 & 0.867 & (0.154) \\ & \text { otherwise } & (0.460) & (0.340) & 0.928 \\ & & & & (0.261)\end{array}$

Visibility conditions

Night

1 if nighttime, 0

0.295

0.399

0.482

otherwise

$(0.456)$

(0.491)

(0.503)

Time of vessel

accident

Year

Accident year, time

2004

2004.53 (1.99)

Vessel damage

trend

(1.7)

2004.24 (1.66)

severity

Damage (D)

1 if vessel damaged, 0

0.373

0.327

(0.484)

(0.470)

0.602

if vessel undamaged

$(0.492)$ 
Table 2. Crew Injuries: Poisson Equation Estimates

\begin{tabular}{|c|c|c|c|}
\hline Variable & $\begin{array}{c}\text { Ferry } \\
\text { Coefficient } \\
\text { (t-statistic) }\end{array}$ & $\begin{array}{c}\text { Ocean Cruise } \\
\text { Coefficient } \\
\text { (t-statistic) }\end{array}$ & $\begin{array}{c}\text { River Cruise } \\
\text { Coefficient } \\
\text { (t-statistic) }\end{array}$ \\
\hline \multicolumn{4}{|l|}{ Type of vessel accident } \\
\hline Allison & $\begin{array}{c}1.481 * * * \\
(4.100)\end{array}$ & & \\
\hline Adrift & $\begin{array}{c}3.866 * * * \\
(5.242)\end{array}$ & & \\
\hline Capsize & $\begin{array}{c}4.098 * * * \\
(6.771)\end{array}$ & & \\
\hline Collision & $\begin{array}{l}1.547^{* *} \\
(2.120)\end{array}$ & $\begin{array}{c}3.443 * * \\
(2.111)\end{array}$ & \\
\hline Explosion & & & $\begin{array}{c}3.196 * * * \\
(4.278)\end{array}$ \\
\hline Grounding & & & $\begin{array}{c}2.151^{* * *} \\
(3.400)\end{array}$ \\
\hline Maneuverability & & $\begin{array}{l}2.107^{*} \\
(1.753)\end{array}$ & $\begin{array}{l}1.203^{* *} \\
(2.296)\end{array}$ \\
\hline \multicolumn{4}{|l|}{ Vessel characteristics } \\
\hline Vessel gross ton & & & $\begin{array}{c}0.244^{* * *} \\
(3.794)\end{array}$ \\
\hline Vessel age & & $\begin{array}{c}-0.401 * * \\
(-2.327)\end{array}$ & $\begin{array}{c}-0.152 * * * \\
(-2.720)\end{array}$ \\
\hline \multicolumn{4}{|l|}{ Type of hull construction } \\
\hline Steel hull & $\begin{array}{c}1.075 * * * \\
(2.586)\end{array}$ & $\begin{array}{c}-3.500 * * * \\
(-4.404)\end{array}$ & \\
\hline Constant & $\begin{array}{c}-4.768 * * * \\
(-11.831)\end{array}$ & $\begin{array}{c}0.113 \\
(0.084)\end{array}$ & $\begin{array}{c}-1.333^{* *} \\
(-2.528)\end{array}$ \\
\hline Number of observations & 1,795 & 263 & 83 \\
\hline Chi-square statistic & $49.60 * * *$ & $53.60 * * *$ & $51.79 * * *$ \\
\hline
\end{tabular}

Note: $\quad * * *$ significant with p-value $<0.01$

$* *$ significant with p-value $<0.05$

* significant with p-value $<0.10$ 
Table 3. Passenger Injuries: Poisson Equation Estimates

\begin{tabular}{lccc}
\hline Variable & $\begin{array}{c}\text { Ferry } \\
\text { Coefficient } \\
\text { (t-statistic) }\end{array}$ & $\begin{array}{c}\text { Ocean Cruise } \\
\text { Coefficient } \\
\text { (t-statistic) }\end{array}$ & $\begin{array}{c}\text { River Cruise } \\
\text { Coefficient } \\
\text { (t-statistic) }\end{array}$ \\
\hline & $1.921^{* * *}$ & $1.469^{* * *}$ & $1.013^{* * *}$ \\
$C_{\text {fit }}$ & $(5.381)$ & $(20.947)$ & $(5.834)$ \\
& $2.909^{* * *}$ & 0.551 & $1.047^{*}$ \\
$D$ & $(14.972)$ & $(1.542)$ & $(1.801)$ \\
& & & $-2.955^{* * *}$ \\
Constant & $-3.735^{* * *}$ & $-2.364^{* * *}$ & $(-4.921)$ \\
\hline Number of observations & $(-19.938)$ & $(-9.747)$ & 83 \\
Chi-square statistic & 1,795 & 263 & $26.89^{* * *}$ \\
\hline
\end{tabular}

Note: $\quad * * *$ significant with p-value $<0.01$

$* *$ significant with p-value $<0.05$

* significant with p-value $<0.10$ 